\title{
SHRINKAGE OF HADDOCK LARVAE Melanogrammus aeglefinus LINNAEUS (1758) PRESERVED IN ETHANOL
}

\section{ENCOGIMIENTO DE LAS LARVAS DE HADDOCK Melanogrammus aeglefinus LINNAEUS (1758) PRESERVADAS EN ETANOL}

\author{
C. Quiñónez-Velázquez \\ G. Chaumillon \\ Département de Biologie \\ Université Laval, \\ Ste. Foy, Qué. G1K 7P4 \\ Canada
}

Recibido en fehrero de 1995; aceptado en noviembre de 1995

\begin{abstract}
Changes in standard length of field-collected larvae and juveniles, due to preservation in $95 \%$ ethanol, werc studicd in haddock ranging from 2.5 to $82 \mathrm{~mm}$ long. Estimates of fresh standard length of haddock from ethanol-preserved specimens show that ethanol causes larvae of all lengths to shrink. The average shrinkage was $26.8 \%$ in newly hatched, $2.5-5 \mathrm{~mm}$, larvae and decreased with increasing sizc. Shrinkage is related to sizc; larger larvac generally shrink proportionally less than smaller larvae.
\end{abstract}

Key words: shrinkage, ethanol, haddock larvae, Scotian Shelf.

\section{RESUMEN}

Se estudiaron los cambios en longitud estándar, debido al efecto de la preservación en etanol al $95 \%$, en larvas de haddock (eglefino) que se recolectaron en el medio natural, con intervalo de 2.5 a $82 \mathrm{~mm}$ de longitud. Las estimaciones de la longitud estándar en fresco, a partir de especímenes piêservados, muestran que el etanol encoge la longitud de la larva sin importar la talla. El encogimiento promedio fue de $26.8 \%$ en larvas de haddock de $2.5-5 \mathrm{~mm}$ (eclosión) y disminuyó con el incremento en longitud. El encogimiento está relacionado con la longitud; las larvas más grandes generalmente se contraen proporcionalmente menos que las larvas más pequeñas.

Palabras clave: encogimiento, etanol, larvas de haddock, plataforma de la Nueva Escocia.

\section{INTRODUCTION}

The nets used in ichthyoplankton surveys collect a large diversity of organisms besides the target species. Individuals must, therefore, be sorted from the bulk catch before any numcrical data or body characteristics can bc

\section{INTRODUCCIÓN}

Las redes que se utilizan en estudios de ictioplancton recolectan un gran número de organismos, además de la(s) especie(s) de interés. Los organismos de estas epecies deben separarse de la captura total antes de que se pueda

\footnotetext{
- Present address: Centro Interdisciplinario de Ciencias Marinas, Playa El Conchalito $s / \mathrm{n}$, apartado postal 592, La Paz, BCS 23000, México. COFAA-IPN member.
} 
determined. In studies of natural conditions, fast classification and analysis of larval fish is difficult and impractical, and samples are usually preserved for later analysis. Body shrinkage is a consequence of multiple causes involved in the capture (tow time, net abrasion, etc.) and preservation media (Blaxter, 1971; Schnack and Rosenthal, 1978; Theilacker, 1980; Hay, 1981, 1982, 1984).

Shrinkage studies are important to predict fresh size for growth and mortality determination. The type of preservative used depends on the purpose of the study and influences the precision with which fresh length can be estimated from preserved length. Most ichthyoplankton is preserved in formalin for taxonomic and feeding studies (Ahlstrom, 1967; Blaxter, 1971); preservation in $95 \%$ ethanol is recommended for age estimation to protect the otoliths (Butler, 1992).

Lengths of larval fish are routinely measured to estimate larval age, growth and mortality. Whatever the purpose of the measurement, larval shrinkage during collections or fixation can result in many errors. The objective of this study was to estimate shrinkage of haddock larvae after preservation in $95 \%$ ethanol and to determine the effect of size on the amount of shrinkage.

\section{MATERIALS AND METHODS}

From March 1991 to May 1993, 27 surveys were conducted along the Scotian Shelf to locate and characterize larval fish populations over Emcrald and Sable Banks (fig. 1). Ichthyoplankton and zooplankton were collected using a $50 \mathrm{~cm}$ bongo, mounted with 150 and $250 \mu \mathrm{m}$ mesh nets (March-May 1991). A rectangular midwater trawl RMT(2-8), with nets of 2 and $8 \mathrm{~m}^{2}$ mouth openings and respective meshes of 333 and 1,600 $\mathrm{mm}$ (June 1991 to May 1993), was also employed. At each station, oblique hauls were made from near the bottom to the surface, at a speed of 2.0-2.5 knots for $30 \mathrm{~min}$ utes, using the bongo and RMT. The majority of fish larvae and all juveniles were immediately sorted from the samples at sea and preserved in $95 \%$ ethanol. The larvae escaping detection registrar cualquier característica numérica. En el campo, la clasificación y el análisis de las larvas de peces es dificil e impráctica. por to que se preservan las muestras para analizarlas posteriormente. El encogimiento en longitud de las larvas de peces es una consecuencia de múltiples causas involucradas en la captura (tiempo de calado, fricción con la red. etc.) y del medio de preservación (Blaxter, 1971; Schnack y Rosenthal, 1978; Theilacker, 1980; Hay, 1981, 1982, 1984).

Los estudios sobre el encogimiento de la longitud son importantes para estimar la longitud en fresco, el crecimiento y la mortalidad de las larvas de peces. El tipo de medio de preservación que se utilice dependerá del propósito del estudio. Generalmente, en estudios taxonómicos y de alimentación, el ictioplancton se preserva en formalina (Ahlstrom, 1967; Blaxter, 1971); en estudios de edad, se recomienda etanol al 95\% (Butler, 1992).

La longitud es necesaria en las estimaciones de la edad, el crecimiento y la mortalidad, y el encogimiento, de no estimarse, producirá errores importantes. El objetivo del presente trabajo fue estimar el encogimiento en longitud de las larvas de haddock (eglefino) preservadas en etanol al $95 \%$ y determinar el efecto de la talla en el encogimiento.

\section{MATERIALES Y MÉTODOS}

Las larvas de haddock fueron recolectadas en cruceros oceanográficos, de marzo de 1991 a mayo de 1993, en la plataforma de la Nueva Escocia, Canadá (fig. 1). Se recolectaron el zooplancton e ictioplancton usando una red bongo de $50 \mathrm{~cm}$ de diámetro de boca y redes con 150 y $250 \mu$ min de luz de malla (miarzo a mayo de 1991). Además, se utilizó una red rectangular de media agua RMT(2-8), con redes de 2 y $8 \mathrm{~m}^{2}$ de abertura de boca y 333 y $1,600 \mu \mathrm{m}$ de luz de malla, respectivamente (junio de 1991 a mayo de 1993). Se efectuaron arrastres oblicuos en cada estación, con una duración de 30 minutos, desde cerca del fondo hasta la superficie a una velocidad de 2.0 a 2.5 nudos. La mayoría de las larvas y los juveniles de haddock se separaron del resto del zooplancton 


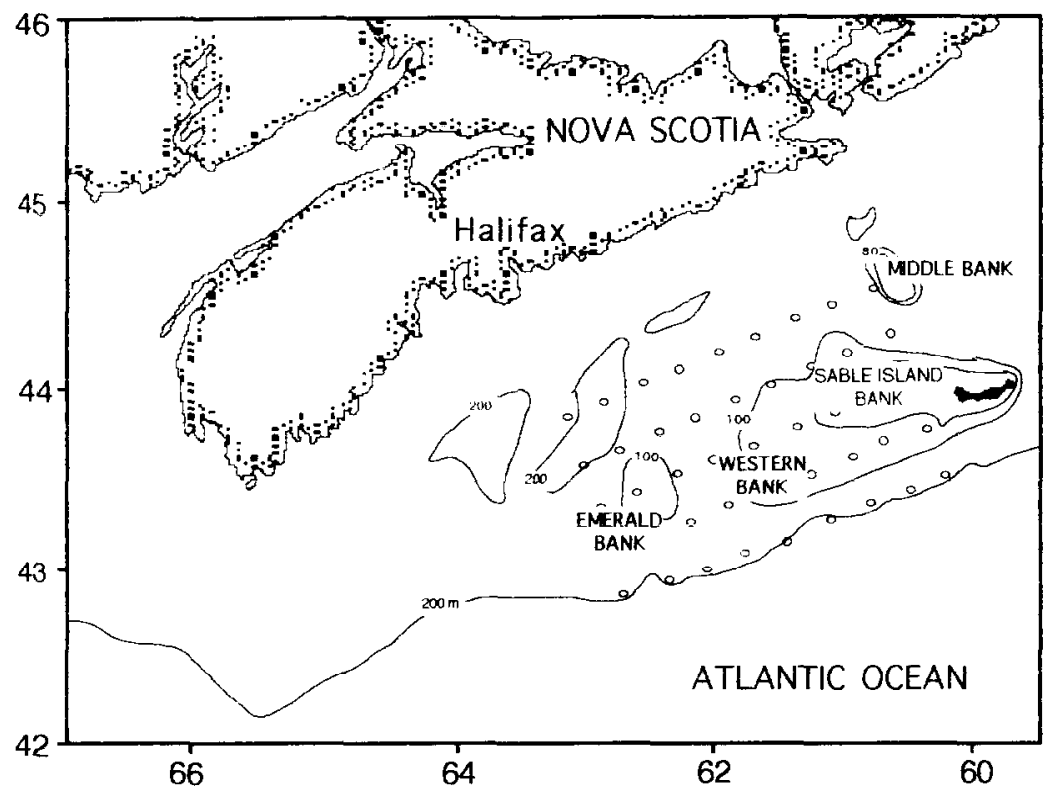

Figure 1. Location of the grid of stations where the haddock larvae were collected from 1991 to 1993, in the Nova Scotia Shelf, Canada.

Figura 1. Localización de la red de estaciones donde se recolectaron las larvas de haddock de 1991 a 1993, en la plataforma continental de la Nueva Escocia, Canadá.

were preserved in $4 \%$ buffered formalin with the remainder of the sample and sorted from other zooplankton in the laboratory. A subset of haddock larvae and juveniles were videotaped, using a stereo dissecting microscope connected to a video camera and magnetoscope. Larvae were then individually preserved in $95 \%$ ethanol. The foregoing is easier and quicker than measuring each one of the larvae and preserving them individually; furthermore, when more than one morphological characteristic needs to be measured, the time involved increases significantly. In the laboratory, the larvae preserved in $95 \%$ ethanol for one to two months after capture were measured to the nearest $0.1 \mathrm{~mm}$, using a stereo dissecting microscope equipped with an ocular micrometer.

Standard length of larvae from videotape images was determined from the image on a television monitor. The screen was linked to a computer and the measurements made using an a bordo del barco y se preservaron inmediatamente en etanol al $95 \%$. Las larvas que no se separaron fueron preservadas en formalina al $4 \%$ con el resto del zooplancton. Antes de ser preservadas, se filmó una submuestra de larvas y juveniles, utilizando un microscopio estereoscópico conectado a una cámara de video y a un magnetoscopio; posteriormente, se preservaron individualmente las larvas en etanol al $95 \%$. Esto es más facil y rápido que medir cada una de las larvas y preservarlas individualmente; además, cuando es necesario medir más de una característica morfológica, el tiempo requerido incrementa significativamente. En el laboratorio, la longitud estándar de las larvas preservadas de uno a dos meses en etanol al $95 \%$ se midió con una precisión de $0.1 \mathrm{~mm}$, utilizando un microscopio estereoscópico con micrómetro ocular.

La longitud estándar en fresco de las larvas que se filmaron se determinó proyectando su 
Table 1. Average percent shrinkage and standard deviation of haddock larvae in the size categories preserved in $95 \%$ ethanol.

Tabla 1. Porcentaje promedio de encogimiento en longitud y desviación estándar de las larvas del haddock preservadas en etanol al $95 \%$.

\begin{tabular}{cccc}
\hline $\begin{array}{c}\text { Fresh length } \\
(\mathrm{mm})\end{array}$ & $\begin{array}{c}\text { Mean shrinkage } \\
(\%)\end{array}$ & SD & N \\
\hline $0-5$ & 26.8 & 3.5 & 33 \\
$5-10$ & 13.2 & 1.9 & 3 \\
$10-15$ & 9.7 & 2.3 & 3 \\
$15-20$ & 9.5 & 3.5 & 51 \\
$20-25$ & 10.4 & 4.0 & 17 \\
$25-30$ & 5.1 & 2.4 & 4 \\
$45-50$ & 2.0 & 0.0 & 1 \\
$50-55$ & 2.0 & 0.3 & 5 \\
$55-60$ & 1.9 & 0.6 & 6 \\
$60-65$ & 2.1 & 0.9 & 3 \\
$65-70$ & 1.8 & 0.4 & 2 \\
$80-85$ & 1.2 & 0.0 & 1 \\
\hline
\end{tabular}

image analysis system (OPTIMAS). The percentage of shrinkage ( $\mathrm{S} \%$ ) for individual larvae was calculated as:

$$
S(\%)=100\left(L_{f}-L_{p}\right) / L_{f}
$$

where $L_{f}$ is the fresh recorded length and $L_{p}$ the preserved length.

\section{RESULTS}

A total of 129 haddock larvae, ranging from 2.5 to $82 \mathrm{~mm}$ preserved standard length, were measured. The larvae with 15 to $82 \mathrm{~mm}$ length were videotaped during the June and July 1991 and May 1993 surveys and come from the east of Sable Island Bank; larvae with 2.5 to $14 \mathrm{~mm}$ length were videotaped during the April and May 1992 surveys and come from Emerald Bank (fig. 1). For analysis, larvae were divided into $5 \mathrm{~mm}$ length classes. Results are presented in table 1. Shrinkage was observed in all preserved larvae. Haddock larvae $<30 \mathrm{~mm}$ showed the most significant shrinkage. Length changes were negligible for preserved haddock larvae $45 \mathrm{~mm}$ and longer. Shrinkage is related to size; imagen en un monitor y utilizando un programa de computadora para análisis de imágenes (OPTIMAS). Se calculó el porcentaje de encogimiento ( $\mathrm{S} \%$ ) de cada larva como:

$$
\mathrm{S}(\%)=100\left(\mathrm{~L}_{\mathrm{f}}-\mathrm{L}_{\mathrm{p}}\right) / \mathrm{L}_{\mathrm{r}}
$$

donde $L_{f}$ es la longitud en fresco y $L_{p}$ la longitud preservada.

\section{RESULTADOS}

Se midió un total de 129 larvas de haddock, con intervalo de 2.5 a $82 \mathrm{~mm}$ de longitud estándar. Las larvas de 15 a $82 \mathrm{~mm}$ de longitud se filmaron durante las campañas de junio y julio de 1991 y de mayo de 1993, y se recolectaron al este de Sable Island Bank; las larvas de 2.5 a $14 \mathrm{~mm}$ de longitud se filmaron durante las campañas de abril y mayo de 1992 , y se recolectaron sobre Emerald Bank (fig. 1). Para el análisis, se agruparon las larvas en intervalos de $5 \mathrm{~mm}$. Los resultados muestran que el encogimiento en longitud se presentó en todas las larvas preservadas (tabla 1). Se observó el encogimiento más importante en larvas 
longer larvae generally shrink proportionally less than shorter larvae.

The average shrinkage was $26.8 \%$ in newly hatched, $2.5-5 \mathrm{~mm}$, haddock larvac and decreased with an increase in size, from 13.2 to $10.4 \%$ for larvae $>5 \mathrm{~mm}$ to $\leq 25 \mathrm{~mm}$, respectively (table 1). Shrinkage of larvae $>30 \mathrm{~mm}$ decreased to a negligible amount, $1.9 \%$ on average. Variability in shrinkage was highest for larvae in the 10 to $25-\mathrm{mm}$ size range, which consisted mostly of first-feeding and early metamorphosed larvae. Percent shrinkage ( $\mathrm{S} \%$ ) was related to fresh standard length $\left(\mathbf{L}_{f}\right)$ with the equation (fig. 2):

$$
\mathrm{S}(\%)=24.31 \mathrm{e}^{\left(-0.043 L_{\mathrm{r}}\right)}\left(\mathrm{r}^{2}=0.76, \mathrm{n}=129\right) .
$$

The relationship between preserved $\left(L_{p}\right)$ and fresh standard length $\left(\mathrm{L}_{f}\right)$ was described by a linear regression for haddock larvac (fig. 3):

$$
\mathrm{L}_{\mathrm{f}}=1.531+1.005 \mathrm{~L}_{\mathrm{p}}\left(\mathrm{r}^{2}=0.99, \mathrm{n}=129\right)
$$

The slope and the intercept are significantly different from zero $(p<0.001)$. Thus, the amount of change in length due to preservation is a function of size.

\section{DISCUSSION AND CONCLUSIONS}

Body shrinkage is a well-documented consequence of capture and preservation (Blaxter, 1971: Schnack and Rosenthal, 1978; Hay, 1981, 1982, 1984; Radtke and Waiwood, 1980; Theilacker, 1980; Hjörleifsson and KleinMacPhee, 1992). Hay (1981) showed that fixation of larval herring immediately following death caused a $5 \%$ decrease in body length, and that a delay of 10 minutes between death and fixation in formalin increased the shrinkage by $30-40 \%$. However, Radtke and Waiwood (1980) found that fixation of reared Gadus morhua larvae in ethanol resulted in body shrinkage that was dependent un the age of the larvae and independent of the time of death. The same pattern was observed in the present study (table 1), where smaller larvae shrank relatively more than larger larvae when fixed in ethanol. This may be because younger fish de haddock $<30 \mathrm{~mm}$. Se observaron cambios minimos en longitud en larvas de haddock $\geq 45 \mathrm{~mm}$. El encogimiento está relacionado con la talla: las larvas más grandes se retraen menos que las larvas más pequeñas.

El encogimiento promedio de las larvas de haddock recién eclosionadas $(2.5$ a $5 \mathrm{~mm}$ de longitud) fue de $26.8 \%$, y disminuyó con el incremento en talla, variando de 13.2 a $10.4 \%$ para larvas $>5 \mathrm{~mm}$ a $\leq 25 \mathrm{~mm}$, respectivamente (tabla 1). El encogimiento promedio en larvas $>30 \mathrm{~mm}$ de longitud disminuyó a $1.9 \%$. La variación en el encogimicnto fue mayor en las larvas de 10 a $25 \mathrm{~mm}$, las cuales consisten principalmente de larvas durante la primera alimentación e iniciando la metamorfosis. El porcentaje de encogimiento $(\mathrm{S} \%)$ se relacionó con la longitud en fresco $\left(L_{f}\right)$ mediante la siguiente ecuación (fig. 2):

$$
S(\%)=24.31 \mathrm{e}^{\left(-0.043 \mathrm{~L}_{\mathrm{r}}\right)}\left(\mathrm{r}^{2}=0.76, \mathrm{n}=129\right) .
$$

La relación entre la longitud estándar preservada $\left(L_{p}\right)$ y la longitud estándar en freseo $\left(L_{\uparrow}\right)$ fue descrita por una regresión lineal (fig. 3):

$$
\mathrm{L}_{\mathrm{f}}=1.531+1.005 \mathrm{~L}_{\mathrm{p}}\left(\mathrm{r}^{2}=0.99, \mathrm{n}=129\right)
$$

La pendiente y el intercepto son significativamente diferentes de cero $(p<0.001)$; esto indica que el efecto de la preservación está en función de la talla de la larva.

\section{DISCUSIÓN Y CONCLUSIÓN}

El encogimiento en longitud es una consecuencia bien documentada en la captura y preservación del ictioplancton (Blaxter, 1971; Schnack y Rosenthal, 1978; Hay, 1981, 1982, 1984; Radtke y Waiwood, 1980; Theilacker, 1980; Hjörleifsson y Klein-MacPhee. 1992). Hay (1981) mostró, para larvas del arenque, que la preservación en formalina inmediatamente después de la muerte causó un encogimiento del $5 \%$ de la longitud, y que un retrazo de 10 minutos entre la muerte y la preservación incrementó la retracción de 30 a $40 \%$. Sin embargo, Radtke y Waiwood (1980) encontraron 


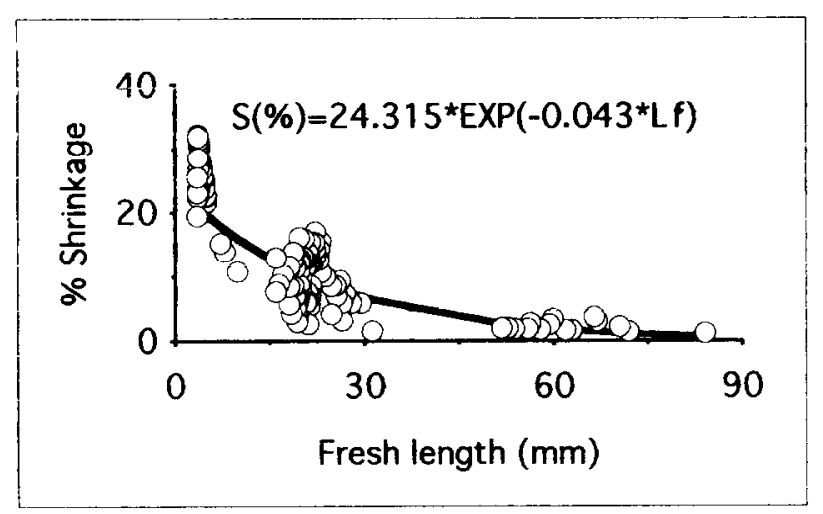

Figure 2. Percent shrinkage $(S \%)$ as a function of fresh length $\left[\mathrm{L}_{i}(\mathrm{~mm})\right]$. An exponential model was fitted to the fresh length data: $S(\%)=24.31 \mathrm{e}^{\left(-0.043 \mathrm{~L}_{\mathrm{r}}\right)}\left(\mathrm{r}^{2}=0.76, \mathrm{n}=129\right)$.

Figura 2. Porcentaje de encogimiento $(\mathrm{S} \%)$ en función de la longitud en fresco $\left[\mathrm{L}_{\mathrm{f}}(\mathrm{mm})\right]$. Se ajustó un modelo exponencial a los datos de longitud en fresco: $S(\%)=24.31 \mathrm{e}^{\left(-0.043 \mathrm{~L}_{r}\right)}\left(\mathrm{r}^{2}=0.76, \mathrm{n}=129\right)$.

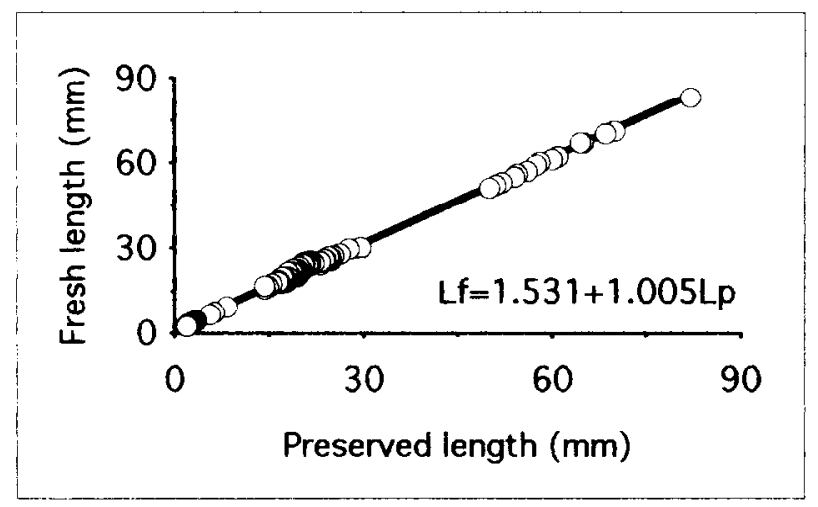

Figure 3. Fresh length $\left[\mathrm{L}_{\mathrm{f}}(\mathrm{mm})\right]$ as a function of the preserved length $\left[\mathrm{L}_{\mathrm{p}}(\mathrm{mm})\right]$. A linear model was fitted to the preserved length data: $L_{f}=1.531+1.005 L_{p}\left(r^{2}=0.99, n=129\right)$.

Figura 3. Longitud en fresco $\left[\mathrm{L}_{\mathrm{f}}(\mathrm{mm})\right]$ en función de la longitud preservada $\left[\mathrm{L}_{\mathrm{p}}(\mathrm{mm})\right]$. Se ajustó un modelo lineal a los datos de la longitud preservada: $L_{f}=1.531+1.005 L_{p}\left(r^{2}=0.99, n=129\right)$.

contain relatively more water that was replaced by the ethanol, or that a more rigid bone structure is present in the bigger fish. Ehrlich (1974) showed that water content of larvae decreased with age and length. Therefore, younger, smaller larvae may stand to lose relatively more water and shrink more than older, larger larvae. que la preservación en etanol de larvas del bacalao Gadus morhua tuvo como resultado un encogimiento de la longitud que fue dependiente de la edad de la larva $\mathrm{e}$ independiente del momento de la muerte. Se observó un patrón semejante en el presente estudio (tabla 1), donde larvas pequeñas se encogen relativamente más que las larvas grandes cuando se 
The normal tow time for ichthyoplankton samples was 30 minutes, and if the larval fish are preserved in $95 \%$ ethanol, it is possible to back-calculate the fresh length for a given preserved length. Nevertheless, we did not consider the shrinkage that takes place while the fish is still within the net.

In conclusion, the preservation of haddock larvae in $95 \%$ ethanol produced body shrinkage, which was dependent on the size of the larvae. On average, newly hatched larvae shrink $27 \%$ in standard length, first-feeding to metamorphosed larvac shrink $10 \%$ and larger larvae shrink $2 \%$.

\section{ACKNOWLEDGEMENTS}

This study was funded by the Natural Sciences and Engineering Research Council of Canada (NSERC), as part of the Ocean Production Enhancement Network (OPEN). C. Quiñonez received additional support from the Instituto Politécnico Nacional and CONACYT (Mexico). We are most grateful to numerous colleagues from Dalhousie, McGill and Laval Universities who assisted with field and laboratory work. The officers and particularly the crew of the R/V Petrel $V$ provided excellent assistance during the execution of the field work. The constructive comments of two anonymous referees are appreciated.

\section{REFERENCES}

Ahlstrom, E.H. (1967). Co-occurrences of sardine and anchovy larvae in the California Current region off California and Baja California. CalCOFI Rep., 11: 117-135.

Blaxter, J.H.S. (1971). Feeding and condition of Clyde herring larvae. Rapp. R.-V. Reun. Cons. Int. Fxplor. Mer, 160: 128-136.

Butler, J.L. (1992). Collection and preservation of material for otolith analysis. In: D.K. Stevenson and S.E. Campana (eds.), Otolith Microstructure Examination and Analysis. Can. Spec. Publ. Fish. Aquat. Sci., 117: 13-17.

Ehrlich, K.F. (1974). Chemical changes during growth and starvation of herring larvae. preservan en etanol. Lo anterior se pucde deber a que las larvas jóvenes contienen relativamente más agua que fue reemplazada por el etanol, y/o a la presencia de una estructura ósea más rígida en larvas más grandes. Ehrlich (1974) mostró que el contenido de agua en larvas de peces disminuye con la edad y la longitud. Por lo tanto, larvas pequeñas y jóvenes pueden perder relativamente más agua y encogerse más que larvas grandes.

El tiempo normal de las recolectas del ictioplancton fue de 30 minutos y, si las larvas de peces se preservan en etanol al $95 \%$, es posible estimar su longitud en fresco a partir de cierta longitud preservada. Resulta necesario señalar que nu se consideró el encogimiento que puede suceder mientras las larvas se encuentran en la red.

En conclusión, la preservación de larvas de haddock en etanol al $95 \%$ produce un encogimiento en longitud, el cual está en función de la talla de la larva. En promedio, las larvas recién eclosionadas se contraen un $27 \%$ de su longitud estándar, las larvas de la primera alimentación a la metamorfosis se contraen un $10 \%$ y las larvas más grandes se contraen un $2 \%$.

\section{AGRADECIMIENTOS}

Estc cstudio fue financiado por el Natural Sciences and Engineering Research Council of Canada (NSERC), como parte del Ocean Production Enhancement Network (OPEN). C. Quiñónez recibió apoyo adicional del Instituto Politécnico Nacional y una beca del CONACYT (México). Estamos muy agradecidos a numerosos colegas de las universidades de Dalhousie, McGill y Laval, quienes nos apoyaron en el trabajo de campo y laboratorio. Los oficiales $y$, en particular, la tripulación del buque Petrel $V$ nos apoyaron muy eficazmente durante el trabajo de campo. Se aprecian los comentarios de dos revisores anónimos.

Traducido al español por los autores.

In: J.H.S. Blaxter (ed.), The Early Life History of Fish. Springer, Heidelberg, pp. 301-323. 
Hay, D.E. (1981). Effects of capture and tixation on gut contents and body size of Pacific herring larvae. Rapp. R.-V. Reun. Cons. Int. Explor. Mer, 178: 395-400.

Hay, D.E. (1982). Fixation shrinkage of herring larvae: effects of salinity, formalin concentration and other factors. Can. J. Fish. Aquat. Sci., 39: 1138-1143.

Hay, D.E. (1984). Weight loss and change of condition factor during fixation of Pacific herring, Clupea harengus pallasi, eggs and larvae. J. Fish Biol., 25: 421-433.

Hjörleifsson, E. and Klein-MacPhee, G. (1992). Estimation of live standard length of winter flounder Pleuronectes americanus larvae from formalin-preserved, ethanol-preserved and frozen specimens. Mar. Ecol. Prog. Ser., 82: 13-19.

Radtke, R.L. and Waiwood, K.G. (1980). Otolith formation and body shrinkage due to fixation in larval cod (Gadus morhua). Can. Tech. Rep. Fish. Aquat. Sci., 929: iii +10 pp.

Schnack, D. and Rosenthal, H. (1978). Shrinkage of Pacific herring larvae due to formalin fixation and preservation. Ber. Deutsch Wiss. Komm. Meeresforsch., 26: 222-226. Theilacker, G.H. (1980). Changes in body measurements of larval northern anchovy, Engraulis mordax, and other fishes due to handling and preservation. Fish. Bull., 78: 685-692. 